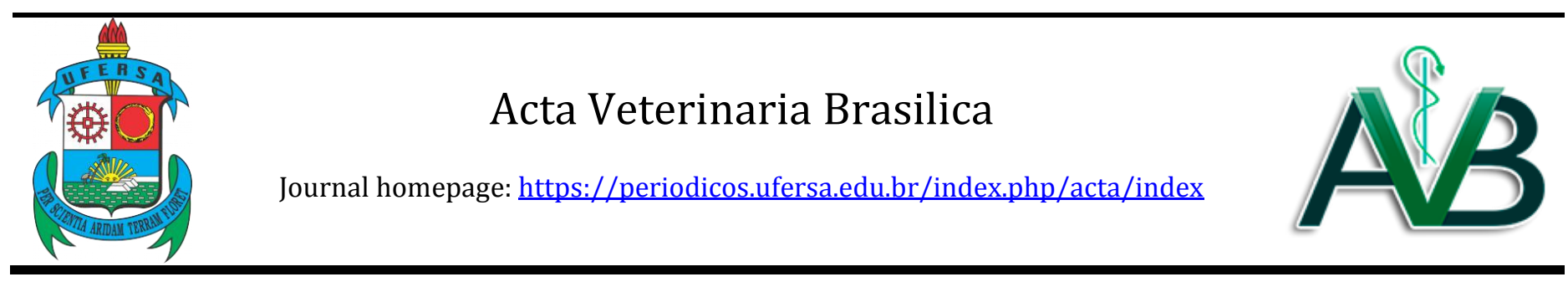

Short Communication

\title{
Bone alkaline phosphatase in donkeys obtained by the thermal inactivation method
}

\author{
Rosany Maria Cunha Aranha ${ }^{1}$, Adriana Vívian Costa Araujoํㄹ $^{2}$, Porfirio Candanedo Guerra3 ${ }^{3}$ Daniel Praseres \\ Chaves ${ }^{4}$, Solange de Araujo Melo ${ }^{4 *}$ \\ 1 Prefeitura Municipal de Paço do Lumiar-MA, SEMAPA-Secretaria Municipal de Agricultura, Paço do Lumiar, Maranhão (MA). \\ 2 Rede Nordeste de Biotecnologia, Doutorado em Biotecnologia em Agropecuária, São Luís, Maranhão (MA). \\ ${ }^{3}$ Universidade Estadual do Maranhão/ UEMA, Centro de Ciências Agrárias, Departamento das Clínicas, São Luís, Maranhão (MA). \\ ${ }^{4}$ Universidade Estadual do Maranhão/ UEMA, Centro de Ciências Agrárias, Departamento de Patologia, São Luís, Maranhão (MA).
}

\section{A R T I C L E I N F O}

\section{Article history}

Received 14 November 2017

Received in revised form 19 December 2017

Accepted 27 December 2017

\section{Keywords:}

Isoenzyme

Diagnosis

Biochemistry

\begin{abstract}
A B S T R A C T
The bone alkaline phosphatase has clinical importance in pathological orthopedic conditions as a marker of the osteoblastic activity, especially in malignant bone tumors and therapeutic monitoring of osteoporosis and other diseases. The reaction of Roy quantitative and qualitative technique of thermal inactivation was applied to obtain bone alkaline phosphatase isoenzyme of male and female donkeys, without defined breed (SRD) aged from seven to 14 months, subjected to the same diet, divided into two groups, composed of five animals each, being the group 1 (G1) kept in confinement and the Group 2 (G2) in traction activity. Blood samples were collected in eight times with an interval of 90 days, during 21 months. The percentage of thermostable isoenzyme was 35 for the G1 and 32 for the G2. It was concluded that the measurements of bone alkaline phosphatase by the thermal inactivation method showed no changes when compared among the groups, demonstrating that the activity of animal traction exerted by the donkeys do not interfere in bone metabolism of these animals.
\end{abstract}

\section{INTRODUCTION}

Define if biochemical markers of bone metabolism as substances that depict the formation or reabsorption of bone tissue (KUO; CHEN, 2017). These processes are usually proportionate, however, there may be changes caused by age, hormonal activity and physical or musculoskeletal diseases (CAMASSA et al., 2017; RAIZ, 1999). The knowledge of the markers of bone metabolism is related to studies of bone biology, assessment of the consolidation of fractures, bone neoplasm, osteoarthritis, preclinical evaluation of the effects of the diets and drugs, in addition to studies of diseases that cause bone changes (CARDOSO et al. 2007; ČEPELAK; ČVORIŠĆEC, 2009).

Alkaline phosphatase is divided into four isoenzymes, in accordance with the tissue where it is produced, which are the intestinal, placental, germ cells and nonspecific, derived from the bone, liver and kidney (SHARMA et al. 2014). Alkaline phosphatase can be used as a bone metabolism marker, being this method safe, reliable, reproducible and inexpensive, although the bone alkaline phosphatase is a specific marker for bone formation (KANWAR, et al. 2014).

The measurement of bone metabolism markers aims to correlate its serum or urinary concentrations with the activity of osteoblasts and osteoclasts (CARDOSO et al., 2010). In general, they are simple, sensitive and accurate methods, with the ability to recognize the progression of metabolic bone diseases or of this tissue response to therapy with drugs (CAMASSA et al., 2017; SHIEH et al., 2016).

\footnotetext{
${ }^{*}$ Corresponding author: sol-vet@hotmail.com
} 
A study performed in premature newborns, with stimulation of bone development by means of physiotherapy as a means of prevention of metabolic alterations in adulthood, presented an increase of approximately $20 \mathrm{U} / \mathrm{L}$ of bone alkaline phosphatase when compared to the control group, indicating an increase in bone formation (VIGNOCHI et al., 2012).

Several methods have been described with the aim of isolating the activity of hepatic isoenzymes and bone, being the most widely used, the specific precipitation with lectins and thermal inactivation (FARLEY et al., 1993). Thus there is interest in studying methodologies that can quantify substances representing metabolic processes underway in this tissue (ČEPELAK; ČVORIŠĆEC, 2009; VIEIRA, 2007).

To recognize the origin of the different isoenzymes of ALP present in the serum or plasma, different techniques can be used (GADE et al., 2011), such as inhibition by Lphenylalanine (KREISHER et al., 1965), urea (BAHR; WILKINSON, 1967), levamisole (CHAN; KELLEN, 1975), homoarginine (FISHMAN; SIE, 1970), electrophoresis (LAAN et al., 1979) and ion exchange chromatography (BARRAL; COSTA, 1990). According to Matos; Sant'Ana (1996), these methods vary widely in cost and complexity. Although the technique of thermal inactivation is simple, inexpensive and relatively efficient, there are few reports of its use in the dosage of this laboratory marker of the osteoblastic activity, especially in veterinary medicine.

The objective of this study was to compare the serum levels of bone alkaline phosphatase among donkeys that exerted activity of animal traction and in confinement regime.

\section{MATERIAL AND METHODS}

This research was approved by the Ethics and Animal Experimentation of the Center for Agrarian Sciences of the Veterinary Medicine Course, State University of Maranhão (UEMA), under the protocol 014/2008 and was carried out according to the ethical principles of the Brazilian College of Animal Experimentation (COBEA).

Ten donkeys clinically healthy, male and female, without defined breed, with seven to 14 months of age were followed for 21 months, receiving feed consisting of elephant grass (Pennisetum purpureum) at libitum and $2 \mathrm{~kg}$ of corn meal/day. The animals were divided into two similar groups in accordance with the activity, being the G1 (group 1) in confinement, kept in an area of the center of the control of zoonoses and the G2 (group 2) in activity of animal traction, together with their respective owners.
$10 \mathrm{~mL}$ of blood were collected without anticoagulant of each animal, at intervals of 90 days, during the entire experimental period, totaling eight collections, performed in the range of eight to nine hours of the morning. After the retraction of the clot and centrifugation at $9000 \mathrm{~g}$, the serum was separated into two aliquots and stored at $-20^{\circ} \mathrm{C}$ in microtubes of polypropylene to the realization of laboratory tests in the Laboratory Cernitas, São Luís Cernitas /MA.

The serum ALP activity was determined by the method of Roy (ROY, 1970) using a commercial kit (Labtest Diagnóstica, Brazil). The serum activity of ALP was obtained by the thermal inactivation method (MATOS; SANT'ANA, 1996). These measurements were carried out in two stages; the first enzyme was inactivated at $37^{\circ} \mathrm{C}$ during $10 \mathrm{~min}$ for the ALP determination and the second was inactivated at $56^{\circ} \mathrm{C}$ for $5 \mathrm{~min}$ for the observation of the thermostable ALP. The results were obtained in absolute values at $37^{\circ} \mathrm{C}$ and in percentage of ALP activity after the thermal inactivation.

The data were analyzed by analysis of variance ( $F$ test), met the assumptions of variances as to homogeneity and normality of errors by tests of Brown and Fortsythe and Cramer-von Mises. For comparison of means among groups and among times in each treatment the Tukey test was used. For all tests, the level of significance was $5 \%$.

\section{RESULTS AND DISCUSSION}

The mean serum activity of G1 was $114.15 \pm 48.79$ IU/L and G2 was $127.26 \pm 43.97 \mathrm{IU} / \mathrm{L}$. The percentage of the thermostable ALP in both groups was 35\% and 32\%, respectively. The values obtained in different moments of evaluation are presented in table 1.

The percentages obtained for the ALP after inactivation at $56^{\circ} \mathrm{C}$, allow us to affirm that this bone isoenzyme, considering the studies of Cadeau; Smith (1973), which established that, for the conditions of $56^{\circ} \mathrm{C}$ during $5 \mathrm{~min}$, values above $58 \%$ indicate a predominance of hepatic ALP and below $50 \%$ predominates the bone ALP.

During the period of 21 months little variation was observed $(\mathrm{P}<0.05)$ in serum activity of the ALP (Table $1)$, without observation of the influence of time on the bone isoenzyme. The relatively short half-life of ALP also serves to justify the similarity among the groups, since the collections were carried out in the morning and always at the same time and, therefore, there was no influence of circadian cycle on this variable. These data are validated by the results found by Aoyama; Shibata (2017), Shao et al. (2003) and Sairanen et al. (1994), describing the circadian cycle as direct and intense influencer on the levels of this marker at night. 
Table 1 - Means and standard deviations of serum activity of alkaline phosphatase (ALP) and bone alkaline phosphatase (bone ALP) of confined donkeys (G1, n=5) and in traction activity (G2, $\mathrm{n}=5$ ).

\begin{tabular}{ccccc}
\hline \multirow{2}{*}{ TIME } & G1 & ALP (U/L) & G1 & Bone ALP (\%) \\
\hline 1 & $105.24 \pm 23.21$ & $155.74 \pm 51.74$ & $32.52 \pm 10.04$ & $25.77 \pm 6.94$ \\
2 & $118.20 \pm 51.71$ & $128.1 \pm 55.79$ & $35.57 \pm 17.23$ & $38.20 \pm 21.19$ \\
3 & $134.30 \pm 54.71$ & $125.1 \pm 52.84$ & $23.1 \pm 7.46$ & $27.97 \pm 16.27$ \\
4 & $132.34 \pm 46.07$ & $118.68 \pm 46.04$ & $41.29 \pm 22.34$ & $41.15 \pm 21.35$ \\
5 & $88.58 \pm 46.76$ & $145.04 \pm 42.03$ & $32.68 \pm 5.81$ & $23.56 \pm 8.20$ \\
6 & $138.08 \pm 69.50$ & $115.62 \pm 26$ & $46.21 \pm 20.64$ & $38.33 \pm 16.87$ \\
7 & $98.18 \pm 54.35$ & $109.8 \pm 37.77$ & $32.05 \pm 14.66$ & $32.17 \pm 9.73$ \\
8 & $96.25 \pm 39.04$ & $118.07 \pm 37.05$ & $41.05 \pm 20.87$ & $34.79 \pm 25.44$ \\
Total & $113.90 \pm 48.16$ & $127.02 \pm 43.65$ & $36.30 \pm 19.30$ & $32.74 \pm 14.50$ \\
\hline
\end{tabular}

There was no difference between parameter and group by the $\mathrm{F}$ test at $5 \%$ significance level.

The activity of animal traction exerted by the donkeys in the G2 did not interfere in the serum activity of total and bone ALP. This result corroborates with the findings of Gomes et al. (2017) that proved that controlled physical activity did not promote changes in relevant biomarkers studied, including the ALP in humans. As a result of this study, Pinto et al. (2006) observed no significant variations of bone ALP in animals with osteoporosis induced by corticosteroids. Trumble et al. (2008) when performing a study on horses with joint injury and healthy, measured bone alkaline phosphatase in serum and synovial fluid, found serum values found below the normal limits in injured animals, which could be related to differences in the osteoblastic activity in relation to the bone remodeling. The same group of study compared the serum levels of alkaline phosphatase also in synovial fluid and serum in accordance with physical activity, obtaining increased values in the synovial fluid and lower than normal in serum as the exercise became routine. It is suggested that during the exercise, the osteoblastic activity increase to the extent that the bone tissue adapts to the loads imposed on it and stabilize the measure that the bone reach an equilibrium level, reducing therefore during a continuous work routine.

Ocarino; Serakides (2006) describe the intense physical effort as liable to cause adverse complex, multifaceted and often contradictory on the bones, and that, depending on the intensity, these effects may take a highly harmful character, and may even cause, from osteoporosis, until the hormonal dysfunctions, resulting in the short term, a reduction of growth factor, causing delay in growth and appearance of locomotor disorders.

Du et al. (2014) identified serum level of bone alkaline phosphatase significantly higher in human patients who presented metastases than in the control group, indicating that the serum bone alkaline phosphatase can be an important biomarker for detection of bone metastases with relatively high diagnostic sensitivity and specificity in patients with cancer.

\section{CONCLUSION}

The measurements of bone alkaline phosphatase by the thermal inactivation method showed no changes when compared among the groups, demonstrating that the activity of animal traction exerted by the donkeys did not interfere in bone metabolism of these animals.

\section{ACKNOWLEDGEMENTS}

To Coordenação de Aperfeiçoamento de Pessoal de Nível Superior - Capes. To Conselho Nacional de Desenvolvimento Científico e Tecnológico - CNPq. To Laboratories Cernitas, São Luiz/MA.

\section{REFERENCES}

AOYAMA, S.; SHIBATA, S. The role of circadian rhythms in muscular and osseous physiology and their regulation by nutrition and exercise. Frontiers in Neuroscience, v. 11, n. 63, p.1-12, 2017.

BAHR, M.; WILKINSON, J.M. Urea as a selective inihibitor of human tissue alkaline phosphatases. Clinica Chimica Acta, v.17, n.3, p.67-375, 1967.

BARRAL, J.M.; COSTA, O.M. Aislamiento de isoenzimas de fosfatasa alcalina en plasma humano, por cromatografia de intercambio iônico. Acta Bioquímica Clínica Latinoamericana, v.24, n.3, p.195-201, 1990.

CADEAU, B.J.; MALKIN, A. A relative stability test for the identification of serum alkaline phosphatase isoenzymes. Clinica Chimica Acta, v.45, n.3, p.235-242, 1973.

CAMASSA, J.A. et al. Bone turnover markers in sheep and goat: A review of the scientific literature. Anais da Academia Brasileira de Ciências, v.89, p.1, p.231-245, 2017.

CARDOSO, M.J.L. et al. Homeostase do cálcio e marcadores do metabolismo ósseo no hipertireoidismo felino - revisão. Archives of Veterinary Science, v.12, n.1, p. 17-27, 2007.

CARDOSO, M.J.L. et al. Marcadores do metabolismo ósseo em gatos. Ciência Rural, v.40, n.8, p.1765-1769, 2010.

ČEPELAK, I.; ČVORIŠĆEC, D. Biochemical markers of bone remodeling review. Biochemia Medica, v.19, n.1, p.17-35, 2009. 
CHAN, A.W.; KELLEN, J.A. Resistance to levamisole (RI2456) in heatstable alkaline phosphatase. Clinica Chimica Acta, v.60, n. 1, p.91-96, 1975.

DU, W. et al.Serum bone-specific alkaline phosphatase as a biomarker for osseous metástases in patients with malignant carcinomas: A systematic review and meta-analysis. Journal of Cancer Research and Therapeutics, v.10, ed.Special-2, p 140-144, 2014.

FARLEY, J.R. et al. Reference standards for quantification of skeletal alkaline phosphatase activity in serum by heat inactivation and lectin precipitation. Clinical Chemistry, v. 39, n.9, p.1878-1884, 1993.

FISHMAN, W.H.; SIE, H.G. L-homoarginine; an inhibitor of serum bone and liver alkaline phosphatase. Clinica Chimica Acta, v.29, n.2, p.339$341,1970$.

GADE, T.P. et al. Imaging of Alkaline Phosphatase Activity in Bone Tissue. PLoS ONE, v.6, n.7, p.1-9, 2011

GOMES, T.S. et al. Effect of Aerobic Exercise on Markers of Bone Metabolism of Overweight and Obese Patients With Chronic Kidney Disease. Journal of Renal Nutrition. v. 27, n.5, p.364-371, 2017.

KANWAR, G. et al. Serum alkaline phosphatase a prospective biomarker for assessment of progress of fracture healing. Impact Factor (JCC). v. 3, n.1, p.15-20, 2014.

KREISHER, J.H. et al. Identification by means of L-phenylalanine inhibition of intestinal alkaline phosphatase components separated by starch gel electrophoresis of serum. Clinica Chimica Acta, v.11, n.2, p.122-127, 1965.

KUO, T.; CHEN, C. Bone biomarker for the clinical assessment of osteoporosis: recent developments and future perspectives. Biomarker Research, v.5, n.18, p.1-9, 2017.

LAAN, H.W. et al. A study of alkaline phosphatase isoenzimes electrophoresis on cellulose acetate compared with agar, agarose and acrilamide in the presence or absence of triton- $x-100$. Clinica Chimica Acta, v.91, n.2, p.147-152, 1979.

MATOS, M.A.A.; SANT’ANA, F.R. Identificação da isoenzima óssea de fosfatase alcalina por termoinativação. Revista Brasileira de Ortopedia, v.31, n.3, p.268-272, 1996.

OCARINO, N.M.; SERAKIDES, R. Efeito da atividade física no osso normal e na prevenção e tratamento da osteoporose. Revista Brasileira de Medicina do Esporte, v.12, n. 3, p. 164-168, 2006.

PINTO, A.S. et al. Efeitos de tratamento combinado de alendronato de sódio, atorvastatina cálcica e ipriflavona na osteoporose induzida com dexametasona em ratas. Revista de Ciências Farmacêuticas Básica e Aplicada, v.42, n.1, p.99-107, 2006.

RAIZ, L. G. Physiology and pathophysiology of bone remodeling. Clinical Chemistry, v.45, n.8, p.1353-1358, 1999.

ROY A.V. Rapid method for determining alkaline phosphatase activity in serum with thymolphthalein monophosphate. Clinical Chemistry, v.16, n.5, p.431- 436, 1970.

SAIRANEN, S. et al. Nocturnal rise in markers of bone resorption is not abolished by bedtime calcium or calcitonin. Clacified Tissue International, v.55, n.5, p.349-52, 1994.

SHARMA, U. et al. Alkaline Phosphatase: An Overview. Indian Journal of Clinical Biochemistry, v.29, n.3, p. 269-278, 2014.

SHAO, P. et al. Circadian rhythms in serum bone markers and their relation to the effect of etidronate in rats. Chronobiology International, v.20, n.2, p.325-36, 2003.
SHIEH, A. et al. Quantifying the Balance Between Total Bone Formation and Total Bone Resorption: An Index of Net Bone Formation. The Journal of Clinical Endocrinology and Metabolism, v.101, n.7, p. 2802-2809, 2016.

TRUMBLE, T. N. et al. Joint dependent concentrations of bone alkaline phosphatase in serum and synovial fluids of horses with osteochondral injury: an analytical and clinical validation. Osteoarthritis and Cartilage, v.16, p.779-786, 2008.

VIEIRA J.G.H. Diagnóstico laboratorial e monitoramento das doenças osteometabólicas. Jornal Brasileiro de Patologia e Medicina Laboratorial, v.43, n.2, p.75-82, 2007.

VIGNOCHI, C. M. et al. Physical Therapy Reduces Bone Resorption and Increases Bone Formation in Preterm Infants. American Journal of Perinatology. v.29, n.08, p.573-578, 2012. 